\title{
Antibiotic Resistance Characterization of Environmental $E$. coli Isolated from River Mula-Mutha, Pune District, India
}

\author{
Rutuja Dhawde ${ }^{1}$, Ragini Macaden ${ }^{2}$, Dhananjaya Saranath ${ }^{3}$, Kayzad Nilgiriwala $^{1}$, \\ Appasaheb Ghadge ${ }^{4}$ and Tannaz Birdi ${ }^{1, *}$ \\ 1 The Foundation for Medical Research, 84A, R.G. Thadani Marg, Worli, Mumbai 400 018, India; \\ rutuja713@gmail.com (R.D.); kayzadnilgiriwala@gmail.com (K.N.) \\ 2 St Johns Research Institute, 100 Feet Rd, John Nagar, Koramangala, Bangalore 560 034, India; \\ ragini.macaden@gmail.com \\ 3 Cancer Patients Aid Association (CPAA), Sumer Kendra, Mumbai 400 0018, India; \\ dhananjaya.saranath@cancer.org.in \\ 4 The Foundation for Research in Community Health, Pune 411007, India; frchpune@bsnl.in \\ * Correspondence: fmr@fmrindia.org; Tel.: +91-22-2493-4989 or +91-22-2493-8601
}

Received: 5 May 2018; Accepted: 5 June 2018; Published: 12 June 2018

\begin{abstract}
In the current study, ceftazidime- and ciprofloxacin-resistant-or dual drug-resistant (DDR) - E. coli were isolated from river Mula-Mutha, which flows through rural Pune district and Pune city. The DDR E. coli were further examined for antibiotic resistance to six additional antibiotics. The study also included detection of genes responsible for ceftazidime and ciprofloxacin resistance and vectors for horizontal gene transfer. Twenty-eight percent of the identified DDR E. coli were resistant to more than six antibiotics, with $12 \%$ being resistant to all eight antibiotics tested. Quinolone resistance was determined through the detection of $q n r A, q n r B, q n r S$ and $o q x A$ genes, whereas cephalosporin resistance was confirmed through detection of TEM, CTX-M-15, CTX-M-27 and SHV genes. Out of 219 DDR E. coli, 8.2\% were $q n r S$ positive and $0.4 \%$ were $q n r B$ positive. Percentage of isolates positive for the TEM, CTX-M-15 and CTX-M-27 genes were $32 \%, 46 \%$ and $0.9 \%$, respectively. None of the DDR E. coli tested carried the $q n r A, \mathrm{SHV}$ and $o q x A$ genes. Percentage of DDR E. coli carrying Class 1 and 2 integrons (mobile genetic elements) were $47 \%$ and $8 \%$, respectively. The results showed that antibiotic resistance genes (ARGs) and integrons were present in the E. coli isolated from the river at points adjoining and downstream of Pune city.
\end{abstract}

Keywords: Mula-Mutha river; antibiotic susceptibility testing; antibiotic-resistant genes; integrons

\section{Introduction}

Antibiotics are required in the treatment of various infectious diseases, namely, diarrhea, pneumonia, urinary tract infections, malaria, tuberculosis and HIV / AIDS [1-5]. However, the present global epidemic of antibiotic-resistant bacteria poses a serious health hazard [6-8]. Various studies have been carried out worldwide to estimate actual global burden of antimicrobial resistance [9]. In Europe, antibiotic-resistant bacteria are responsible for the deaths of more than 25,000 patients annually and costs at least $€ 1.5$ billion [10]. In the United States, 63,000 deaths occur annually due to antibiotic-resistant bacteria and costs the US health system from 21 to 34 billion dollars annually [9]. Additionally, antibiotic groups, such as cephalosporins and fluoroquinolone, are commonly used worldwide in agriculture practices and in poultry as growth promoters at subtherapeutic doses and to prevent and treat infections [11,12]. 
In the Indian public health sector, $50 \%$ of family spending is associated with unnecessary medications, especially antibiotic treatment [13-15]. Nontherapeutic use of antibiotics is also common in the Indian subcontinent, as it is recorded in apiary, poultry, agriculture and aquaculture [16]. Traces of ciprofloxacin, chloramphenicol and erythromycin were detected in branded honey [16]. Colistin, a last resort of antibiotic, was used as a growth promoter in a poultry farm located near Hyderabad city [17]. Antibiotics have also been added to fish and crustacean sea foods in Tamilnadu state prior to export [16]. This increased and indiscriminate use of antibiotics for treatment, in animal husbandry, aquaculture and food preservation in the last two decades has contributed to the growing pool of antibiotic-resistant bacteria $[9,18]$.

The World Health Organization (WHO) endorsed a global action plan in May 2015 to circumvent antimicrobial resistance. This plan is mainly focused on increasing awareness, understanding, surveillance and research on antibiotic resistance towards optimizing antibiotic use, and investment in new drugs, diagnostic tools and vaccines [19]. Government of India has also initiated a 5-year National Action Plan (2017-2021) to combat antibiotic resistance. Under the National Action Plan, Indian Council of Medical Research (ICMR) has set up National Anti-Microbial Resistance Research and Surveillance Network (AMRRSN) to compile national antimicrobial resistance (AMR) data. AMRRSN is focusing on surveillance of diarrheagenic bacterial pathogens, enteric pathogens, enteric organism causing sepsis, Gram-negative non-fermenters and Gram-positive methicillin-resistant Staphylococcus aureus [20].

The pathogens selected by AMRRSN are not only clinically important but also play a crucial role in the environment by disseminating antibiotic resistance. These pathogens enter fresh and marine waterbodies through sewage disposal [21,22]. The environment plays a critical role in the generation of antibiotic resistance in bacteria. Residual antibiotics in wastewater as pollutants can exert selective pressure and contribute to the increase in antibiotic-resistant bacteria [23]. Sewage from hospitals and the community, agricultural effluent and aquaculture wastewater are also important sources of resistant bacteria polluting the water sources [23-25].

Increasing load of antibiotic-resistant bacteria in Indian rivers is a major health concern. Added to this is the inefficient/inadequate sewage treatment, resulting in improperly treated waste being released into rivers $[4,15]$. Multidrug-resistant bacteria in water sources is a recognized health hazard to the community [26]. Multidrug-resistant bacteria have been isolated from major Indian rivers, including Ganges, Yamuna and Cauvery [27-29].

Mula-Mutha is a major river in Pune district in Maharashtra state of India and passes through the center of Pune city. It is a confluence of two rivers, namely, the Mula and Mutha rivers. These two rivers merge at Sangam wadi village, flow through different regions of Pune district and, finally, merge with the river Bhima. It is a monsoon-based river which usually gets its water during the monsoon and dries up in summer. It receives waste from agricultural runoff, disposal of waste, burning of fossil fuels and domestic, hospital and industrial effluents (from small- and large-scale industries) located along the banks of the river [30].

Various new and emerging antibiotic resistance genes (ARGs) have been reported in bacteria isolated from the environment [31]. Recent metagenomic studies revealed that ARGs that cluster in soil and wastewater treatment plants (WWTPs) differ significantly from the ARGs of human pathogens [32-34]. Acquisition of resistance genes by bacteria in the environment occurs primarily through horizontal gene transfer. Horizontal gene transfer is facilitated through a variety of mobile gene elements (MGEs), such as plasmids, bacteriophages, genomic islands (GIs), integrative and conjugative elements (ICEs), insertion sequences (ISs), transposons (Tns), integrons and miniature inverted repeat transposable elements (MITEs) [35].

E. coli from the Enterobacteriaceae family occur as commensals in human and animal gut [36]. Fluoroquinolones and third-generation cephalosporins are the most commonly used antibiotics in many developing countries, resulting in injudicious use of these antibiotics [37]. $\beta$-Lactamases are enzymes produced by microorganisms to inactivate the antibiotics containing $\beta$-lactam rings [38]. $\beta$-Lactamases can be classified in two different ways, namely, molecular and 
functional classifications [39]. The molecular classification considers the amino acid sequences. Class A, C, D utilize serine for $\beta$-lactam hydrolysis and Class B uses metalloenzymes, which require divalent zinc ions as a cofactor for substrate hydrolysis [39]. Based on functional groups, $\beta$-lactamases are classified into three groups, namely, Group 1 cephalosporinases; Group 2 penicillinases, extended-spectrum $\beta$-lactamases and serine carbapenemases; and Group 3 metallo- $\beta$-lactamases [38]. Extended spectrum $\beta$-lactamase (ESBL) production in Gram-negative bacteria enables resistance to a wide variety of penicillin and cephalosporin antibiotics. Additionally, some E. coli produce New Delhi metallo- $\beta$-lactamase (NDM-1) enzyme that makes them resistant to virtually all $\beta$-lactams, including carbapenem [40]. In the case of quinolone resistance, both plasmid and chromosomally mediated resistance are common in E. coli, while cephalosporin resistance is commonly coded by plasmids [37].

In the present study, river water samples were screened for ciprofloxacin (fluoroquinolone)and ceftazidime (third-generation cephalosporin)-resistant thermotolerant fecal coliforms (i.e., dual drug-resistant (DDR) TFC). Further, ciprofloxacin- and ceftazidime-resistant $E$. coli were isolated from DDR TFC and were subjected to antibiotic susceptibility testing to determine their antibiotic resistance profile and ESBL production. DDR E. coli were also tested for genes coding for $\beta$-lactamase production (TEM, SHV, CTX-M-15 and CTX-M-27) and quinolone resistance ( $q n r A, q n r B, q n r S$, oqxA) and horizontal gene transfer (HGT) genes-the Class 1 and 2 integrons (intI1, intI2).

\section{Materials and Methods}

\subsection{Study Area and Sample Collection}

Eight sampling sites along the Mula-Mutha river were selected, covering the whole length of the river including upstream, confluence and downstream locales with respect to Pune city. Of the eight sampling points, six were from rural and two were from urban Pune (Figure 1). The distance between sampling points ranged from $5-40 \mathrm{~km}$. Three water samples per site were collected over a period of 1 year. The samples were collected three times over a period of 1 year: during post-monsoon (January 2016), pre-monsoon (May 2016) and monsoon (August 2016). Approximately $400 \mathrm{~mL}$ river water was collected in previously autoclaved $500 \mathrm{~mL}$ polypropylene bottles from $60 \mathrm{~cm}$ beneath the river surface. These bottles were immediately kept on ice and transported to the laboratory in Mumbai (6-8 h) on the same day, stored overnight between $4-8{ }^{\circ} \mathrm{C}$, and bacteriological analysis was undertaken on the following day [41]. Bacterial analysis of the water samples was carried out as per the specifications given by the Bureau of Indian Standards [42].

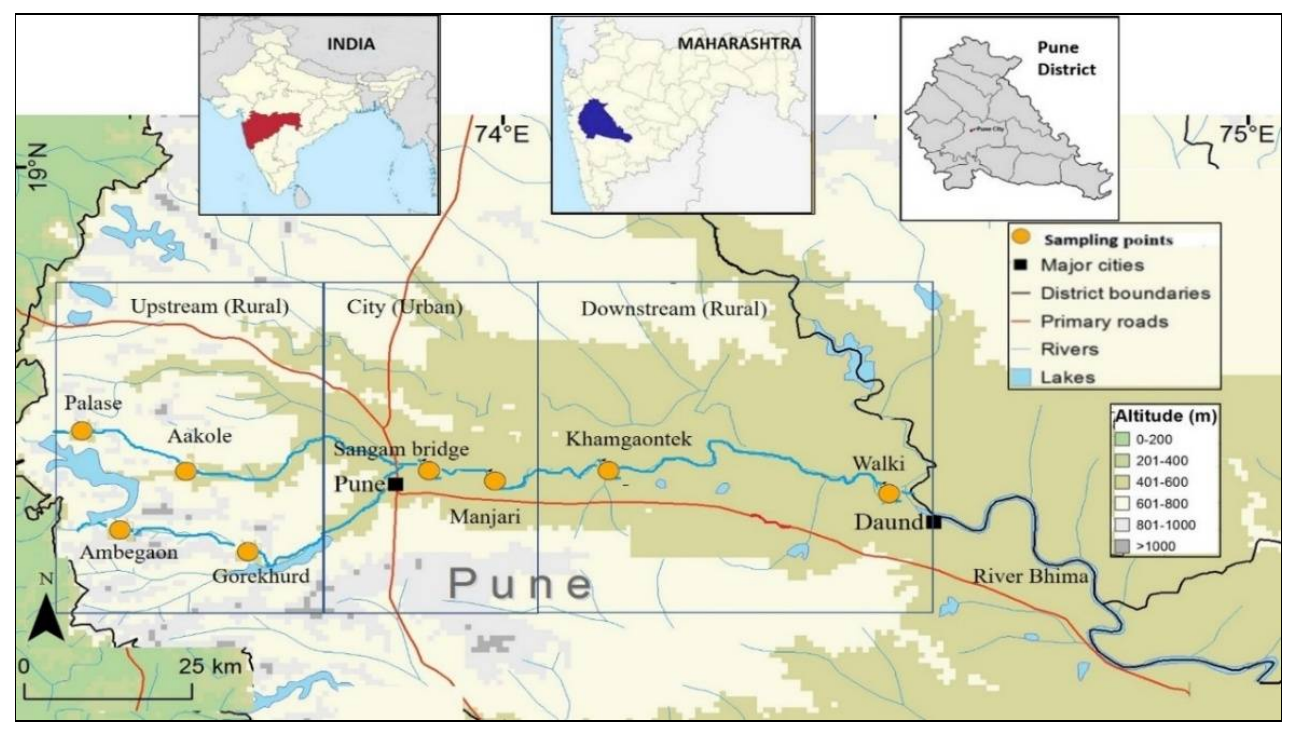

Figure 1. Distribution of sampling points across Mula and Mutha river. 


\subsection{Isolation of Dual Drug-Resistant (DDR) E. coli}

Selection of antibiotics for the study was based on literature survey [43,44] and information obtained regarding antibiotics prescribed by Public Health Centre (PHC) doctors or private practitioners and over-the-counter antibiotics dispensed by private and PHC chemists in selected villages (data not shown).

To isolate and enumerate dual drug-resistant (DDR) TFC, cellulose acetate filter-sterilized ceftazidime $(16 \mu \mathrm{g} / \mathrm{mL})$ and ciprofloxacin $(4 \mu \mathrm{g} / \mathrm{mL})$ were added to membrane fecal coliform (m-FC) agar prior to pouring into Petri dishes. The concentrations of antibiotics used were as per Centre for Clinical and Laboratory Standards Institute guidelines [45]. DDR TFC were enumerated using different volumes of water ranging from $10^{-2} \mathrm{~mL}$ to $10^{2} \mathrm{~mL}$ filtered through cellulose acetate $0.22 \mu$ filters (Merck Millipore, Darmstadt, Germany). The filter papers were placed face-upward on m-FC agar and incubated at $44.5^{\circ} \mathrm{C}$ for $24 \mathrm{~h}$. The filter papers were observed for blue colored colonies and results expressed as colony forming units (CFU) per $100 \mathrm{~mL}$. Additionally, the total TFC was enumerated using the membrane filtration technique and $\mathrm{m}-\mathrm{FC}$ medium without incorporating antibiotics into the medium. DDR TFC colonies were streaked on Hichrome E. coli agar (Himedia, Mumbai, India). Bluish-green colonies on the media represented DDR E. coli. Dual drug-resistant E. coli were preserved in $15 \%$ glycerol stocks in sterile Luria Bertani broth and stored at $-20^{\circ} \mathrm{C}$ [45]. Cell density of DDR E. coli in the glycerol stock was maintained as $10^{8}$ cells $/ \mathrm{mL}$.

\subsection{Antibiotic Susceptibility Testing}

To revive DDR E. coli from frozen glycerol stock, $0.1 \mathrm{~mL}$ of stock was added to $1 \mathrm{~mL}$ Luria Bertani broth (Himedia, Mumbai, India) and incubated overnight at $37^{\circ} \mathrm{C}$ with aeration. The resultant actively growing DDR E. coli culture was centrifuged at $6797 \times g$ for $10 \mathrm{~min}$ in an Eppendorf centrifuge 5430 (Hamburg, Germany). The supernatant was decanted. Cells were washed with saline and centrifuged again at $6797 \times g$ for $10 \mathrm{~min}$ followed by decanting of the supernatant. Saline was added to the DDR E. coli pellet followed by cell density adjustment to $10^{8}$ cells $/ \mathrm{mL}$ using MacFarland standard of 0.5 (which is equal to a cell density $1.5 \times 10^{8} \mathrm{CFU} / \mathrm{mL}$ ) (Himedia, Mumbai, India). After adjusting the cell density, DDR E. coli were subjected to antibiotic susceptibility test (AST) by disk diffusion method on Mueller Hinton agar plates (Himedia, Mumbai, India) [46]. E. coli ATCC25922-a pan-sensitive strain-served as a negative control [47]. Hexadisc G15 minus (Himedia, Mumbai, India) containing a panel of six antibiotics was used for susceptibility testing. The six antibiotics in the Hexadisc were ampicillin $(10 \mu \mathrm{g})$, cefepime $(30 \mu \mathrm{g})$, cefotaxime $(30 \mu \mathrm{g})$, gentamicin $(10 \mu \mathrm{g})$, imipenem $(10 \mu \mathrm{g})$ and piperacillin/tazobactam $(10 / 10 \mu \mathrm{g})$. Antibiotic resistance was estimated by measuring the respective zones of inhibition (diameters) around each antibiotic disk as per Clinical and Laboratory Standards Institute [45]. The presence of ESBLs was confirmed by double-disk synergy test using ceftazidime $(30 \mu \mathrm{g})$ and a combination of ceftazidime $(30 \mu \mathrm{g})$ and clavulanic acid $(10 \mu \mathrm{g})$ [48].

\subsection{Genetic Determinants of Antibiotic Resistance and Horizontal Gene Transfer (HGT) in DDR E. coli (HGT)}

Glycerol stock of DDR E. coli was revived in Luria Bertani broth. Overnight culture of DDR E. coli was centrifuged at $6797 \times g$ for $10 \mathrm{~min}$ followed by DNA extraction using PureLink ${ }^{\circledR}$ Genomic DNA Kit (Invitrogen, CA, USA). The DNA was subjected to agarose gel electrophoresis (AGE) in 1\% agarose gel, quantitated using NanoDrop 2000 (Thermo Fisher Scientific, MA, USA) at 260 and $280 \mathrm{~nm}$ and amplified by polymerase chain reaction (PCR) using Master Cycler Gradient (Eppendorf, Hamburg, Germany). Specific primers to TEM, SHV, CTX-M-15, CTX-M-27, qnrA, qnrB, qnrS, intI1, intI2, oqxA genes were purchased from Sigma Aldrich (MO, USA) (sequences detailed in Table 1). PCR master mix was purchased from Bioron (Ludwigshafen, Germany). The PCR was carried out in a final volume of $25 \mu \mathrm{L}$. Absence of PCR inhibitors in the sample DNAs was observed by PCR amplification of at least one gene of investigation in the majority $(86 \%)$ of the extracted DNA from the identified isolates. 
Table 1. Sequences of primers, PCR conditions, annealing temperature for amplifying target genes.

\begin{tabular}{|c|c|c|c|c|c|}
\hline Description & Target Genes & Sequence $\left(5^{\prime}-3^{\prime}\right)$ & Amplicon Size & $\begin{array}{l}\text { Annealing } \\
\text { Temp }\left({ }^{\circ} \mathrm{C}\right)\end{array}$ & Reference \\
\hline \multirow{4}{*}{$\beta$-Lactamase } & SHV & $\begin{array}{l}\text { FP: AGCCGCTTGAGCAAATTAAAC } \\
\text { RP: ATCCCGCAGATAAATCACCAC }\end{array}$ & 713 & \multirow[t]{2}{*}{64} & \multirow{4}{*}{ [49] } \\
\hline & TEM & $\begin{array}{l}\text { FP: CATTTCCGTGTCGCCCTTATTC } \\
\text { RP: CGTTCATCCATAGTTGCCTGAC }\end{array}$ & 800 & & \\
\hline & CTX-M-15 & $\begin{array}{l}\text { FP: TTAGGAARTGTGCCGCTGYA } \\
\text { RP: CGATATCGTTGGTGGTRCCAT }\end{array}$ & 688 & \multirow{2}{*}{62} & \\
\hline & CTX-M-27 & $\begin{array}{l}\text { FP: TCAAGCCTGCCGATCTGGT } \\
\text { RP: TGATTCTCGCCGCTGAAG }\end{array}$ & 561 & & \\
\hline \multirow{4}{*}{$\begin{array}{l}\text { Plasmid-mediated } \\
\text { quinolone resistance }\end{array}$} & $q n r A$ & $\begin{array}{l}\text { FP: AAGGAAGCCGTATGGATATT } \\
\text { RP: AGCTAATCCGGCAGCACTAT }\end{array}$ & 670 & \multirow{3}{*}{54} & \multirow{3}{*}{ [50] } \\
\hline & $q n r B$ & $\begin{array}{l}\text { FP: CGACCTGAGCGGCACTGAAT } \\
\text { RP: TGAGCAACGATGCCTGGTAG }\end{array}$ & 515 & & \\
\hline & qnrS & $\begin{array}{l}\text { FP: ACCTTCACCGCTTGCACATT } \\
\text { RP: CCAGTGCTTCGAGAATCAGT }\end{array}$ & 571 & & \\
\hline & $o q x A$ & $\begin{array}{c}\text { FP: CTCGGCGCGATGATGCT } \\
\text { RP: CCACTCTTCACGGGAGACGA }\end{array}$ & 280 & 64 & [51] \\
\hline \multirow{2}{*}{$\begin{array}{l}\text { Horizontal gene } \\
\text { transfer }\end{array}$} & intI1 & $\begin{array}{l}\text { FP: CCTCCCGCACGATGATC } \\
\text { RP: TCCACGCATCGTCAGGC3 }\end{array}$ & 280 & 55 & [52] \\
\hline & int 12 & $\begin{array}{l}\text { FP: CACGGATATGCGACAAAAAGGT } \\
\text { RP: GTAGCAAACGAGTGACGAAATG }\end{array}$ & 788 & 55 & [53] \\
\hline
\end{tabular}

In the present study, TEM, CTX-M-15, CTX-M-27 were multiplexed as Group I; qnrA, qnrB and $q n r S$ formed multiplexed as Group II; oqxA, SHV were multiplexed as Group III; and intI1 and intI2 were amplified individually. The PCR conditions used for multiplexes and single-plex were as follows: initial denaturation at $95^{\circ} \mathrm{C}$ for $120 \mathrm{~s}$, followed by 32 cycles of amplification at $95{ }^{\circ} \mathrm{C}$ for $45 \mathrm{~s}$, annealing at different temperatures as mentioned in Table 1 . The temperature for extension was $72{ }^{\circ} \mathrm{C}$ for $60 \mathrm{~s}$. The final extension was at $72{ }^{\circ} \mathrm{C}$ for $5 \mathrm{~min}$. The extension for integron PCRs was carried out for $68^{\circ} \mathrm{C}$ for $60 \mathrm{~s}$. PCR products were electrophoresed on $1.5 \%(w / v)$ agarose gel and stained with ethidium bromide. Additionally, representative positive PCR products were subjected to Sanger sequencing through an ABi 3730X1 sequencer (Applied Biosystem, CA, USA). DDR E. coli harboring different ARGs and mobile genetic elements were enumerated.

Correlation between HGT and $\beta$-lactamase or fluoroquinolone resistance was analyzed by statistical $\chi^{2}$-test.

PCR Conditions were as follow.

Initial denaturation was carried out at $95^{\circ} \mathrm{C}$ for $120 \mathrm{~s}$,

denaturation at $94^{\circ} \mathrm{C}$ for $45 \mathrm{~s}$,

annealing with different temperatures, mentioned in Table 1 ,

extension at $72{ }^{\circ} \mathrm{C}$ for $60 \mathrm{~s}$,

final extension at $72{ }^{\circ} \mathrm{C}$ for $120 \mathrm{~s}$.

32 cycles.

Note: In the case of integron PCR, extension was carried out for $68^{\circ} \mathrm{C}$ for $60 \mathrm{~s}$.

\section{Results}

\subsection{Antibiotic Resistance Profile of DDR E. coli}

The ratio of DDR E. coli to TFC was calculated and expressed in percentages across different sampling sites (Table 2). The average load of DDR E. coli was found to be $4.3 \times 10^{4} \mathrm{CFU} / 100 \mathrm{~mL}$ in Mula-Mutha river over a period of 1 year, and 219 isolates were tested for phenotypic and genotypic resistance. 
Table 2. Dual drug-resistant (DDR) E. coli load at different sites and their antibiotic resistance profile.

\begin{tabular}{|c|c|c|c|c|c|c|c|c|c|c|}
\hline \multirow{5}{*}{ Sampling Site } & \multicolumn{10}{|c|}{ DDR E. coli-CP and CZ Resistant (\%) } \\
\hline & \multirow{4}{*}{$\mathrm{CFU}\left(\log _{10}\right) / 100 \mathrm{~mL}[\%]$} & \multicolumn{9}{|c|}{ Resistance to } \\
\hline & & \multirow{2}{*}{$\begin{array}{c}\text { Fluro-Quinolone } \\
\mathrm{CP} \\
\end{array}$} & \multicolumn{3}{|c|}{ Cephalosporin } & \multirow{2}{*}{$\begin{array}{c}\text { Penicillin } \\
\text { AMP }\end{array}$} & \multirow{2}{*}{$\begin{array}{c}\text { Carbapenem } \\
\text { IMP }\end{array}$} & \multirow{2}{*}{$\begin{array}{c}\begin{array}{c}\text { Amino } \\
\text { Glycoside }\end{array} \\
\text { GN }\end{array}$} & \multirow{2}{*}{$\begin{array}{c}\beta \text {-Lactam and } \\
\text { Inhibitor }\end{array}$} & \multirow{2}{*}{$\begin{array}{c}\begin{array}{c}\text { ESBL } \\
\text { Production }\end{array} \\
\mathrm{CZ}+\mathrm{CZL}\end{array}$} \\
\hline & & & $\mathrm{CZ}$ & CTX & CPM & & & & & \\
\hline & & & (3rd gen) & (3rd gen) & (4th gen) & & & & & \\
\hline KT & 1.99 [2.2] & 94 & 94 & $94(100)$ & 75 (79) & $94(100)$ & $44(46)$ & $16(17)$ & $71(75)$ & $6(6)$ \\
\hline MJ & $3.61[1.2]$ & 60 & 60 & $57(92)$ & $41(68)$ & $60(100)$ & $26(43)$ & $5(8)$ & $33(55)$ & $6(10)$ \\
\hline SB & 5.09 [1.8] & 65 & 65 & 64 (98) & $49(75)$ & $65(100)$ & $29(44)$ & $12(18)$ & $56(86)$ & $10(15)$ \\
\hline Total & & & 219 & $215(98)$ & $165(75)$ & 219 (100) & $99(45)$ & $33(15)$ & $160(73)$ & $22(10)$ \\
\hline
\end{tabular}

Abbreviations: KT: Khamgaontek, MJ: Manjari, SB: Sangam Bridge, CFU: Colony forming units, EBSL: Extended spectrum $\beta$-lactamase, CP: Ciprofloxacin, CZ: Cephatazidime, CTX: Cefotaxime, CPM: Cefepime, AMP: Ampicillin, IMP: Imipenem, GN: Gentamicin, PIT: Piperacillin with Tazobactam. 
DDR E. coli were not detected in the river upstream (Palase, Aakole, Ambegaon, Gorekhurd) and extreme downstream (Walki) of Pune city. The load was concentrated at Sangam bridge, Manjari and Khamgaontek, which constitute confluence of Mula and Mutha rivers, in the city and downstream of city (Table 2). Percentages of DDR E. coli showing resistance at points adjoining and downstream of Pune city to various antibiotics and ESBL production are detailed in Tables 2 and 3. It was found that $63 \%$ were resistant to more than six antibiotics, with $28 \%$ being resistant to all the eight antibiotics tested (Table 3). All DDR E. coli showed resistance to ampicillin. Ninety-eight percent of the isolates were resistant to cefotaxime, which is a third-generation cephalosporin-like ceftazidime. Resistance to cefepime (fourth-generation cephalosporin) and piperacillin/tazobactam combination was $75 \%$ and $73 \%$, respectively. Forty-five percent of DDR E. coli were resistant to imipenem, which is considered as a "reserve "antibiotic. Resistance to gentamicin was noted in 33\% of the isolates (Table 2). Only 10\% of the isolates were ESBL producers (Table 2).

Table 3. Extended antibiotic resistance profile of DDR E. coli.

\begin{tabular}{|c|c|c|}
\hline Resistance to Number of Antibiotics & $\begin{array}{l}\text { Ciprofloxacin and Ceftazidime }(C Z)+ \\
\text { Additional Antibiotics }\end{array}$ & Resistant Isolates (\%) \\
\hline 3 & $\mathrm{AMP} / \mathrm{CPM} / \mathrm{CTX} / \mathrm{PIT}$ & $4(1.8)$ \\
\hline 4 & $\begin{array}{c}\text { CTX and AMP/IMP/GN/PIT/CPM } \\
\text { CPM and AMP/IMP/GN/PIM } \\
\text { GN and IMP/PIT } \\
\text { IMP and PIT }\end{array}$ & $22(10)$ \\
\hline 5 & $\begin{array}{c}\mathrm{CTX}+\mathrm{CPM} \text { and AMP/IMP/GN/PIT } \\
\mathrm{CTX}+\mathrm{AMP} \text { and IMP/GN/PIT } \\
\mathrm{CTX}+\mathrm{IMP} \text { and GN/PIT } \\
\mathrm{CTX}+\mathrm{IMP} \text { and GN/PIT } \\
\mathrm{CPM}+\mathrm{AMP} \text { and IMP } / \mathrm{GN} / \mathrm{PIT} \\
\mathrm{AMP}+\mathrm{GN} \text { and PIT } \\
\text { IMP + GN and PIT }\end{array}$ & $39(17.8)$ \\
\hline 6 & $\begin{array}{c}\mathrm{CTX}+\mathrm{CPM}+\mathrm{AMP} \text { and IMP/PIT } / \mathrm{GN} \\
\mathrm{CTX}+\mathrm{AMP}+\mathrm{IMP} \text { and GN/PIT } / \mathrm{CPM} \\
\mathrm{AMP}+\mathrm{IMP}+\mathrm{GN} \text { and PIT/CPM/CTX } \\
\mathrm{AMP}+\mathrm{GN}+\mathrm{PIT} \text { and CTX } \\
\mathrm{AMP}+\mathrm{PIT}+\mathrm{CTX} \text { and CPM } \\
\mathrm{IMP}+\mathrm{GN}+\mathrm{PIT} \text { and CTX } \\
\mathrm{IMP}+\mathrm{PIT}+\mathrm{CTX} \text { and CPM } \\
\mathrm{IMP}+\mathrm{CTX}+\mathrm{CPM} \text { and AMP } \\
\mathrm{GN}+\mathrm{PIT}+\mathrm{CTX} \text { and CPM } \\
\mathrm{GN}+\mathrm{CTX}+\mathrm{CPM} \text { and AMP } \\
\mathrm{GN}+\mathrm{CPM}+\mathrm{AMP} \text { and IMP }\end{array}$ & $63(28.7)$ \\
\hline 7 & $\begin{array}{l}\mathrm{CTX}+\mathrm{CPM}+\mathrm{AMP}+\mathrm{IMP} \text { and GN/PIT } \\
\mathrm{CTX}+\mathrm{CPM}+\mathrm{GN}+\mathrm{PIT} \text { and AMP/IMP }\end{array}$ & $63(28.7)$ \\
\hline 8 & $\mathrm{CP}+\mathrm{CZ}+\mathrm{CTX}+\mathrm{CPM}+\mathrm{AMP}+\mathrm{IMP}+\mathrm{GN}+\mathrm{PIT}$ & $28(12.7)$ \\
\hline
\end{tabular}

Abbreviations: CP: Ciprofloxacin, CZ: Cephatazidime, CTX: Cefotaxime, CPM: Cefepime, AMP: Ampicillin, IMP: Imipenem, GN: Gentamicin, PIT: Piperacillin with Tazobactam.

\subsection{Detection of Genes Responsible for Fluoroquinolone and Cephalosporin Resistance in DDR E. coli}

Fluoroquinolone: All isolates were examined for the presence of plasmid-mediated genes $q n r A, B$, $S$ and efflux pump-mediated gene oq $x A$. A single isolate from total of 219 tested harbored $q n r B$ and 18 isolates harbored the qnrS gene. No isolate contained either $q n r A$ or oqxA genes.

Cephalosporin: The DDR E. coli harbored CTX-M-15 (46\%) and TEM (32\%), and 10\% of the isolates harbored both TEM and CTX-M-15. Two isolates carried both the genes CTX-M-27 and TEM. None of the isolates harbored SHV (Table 4).

Although the 219 DDR E. coli were initially isolated as colonies resistant to ceftazidime and ciprofloxacin, only $4.5 \%$ of the isolates harbored resistant genes for both antibiotics (TEM and $q n r S$ ). 
Table 4. DDR E. coli (\%) detected with specific resistance and/or with integrons.

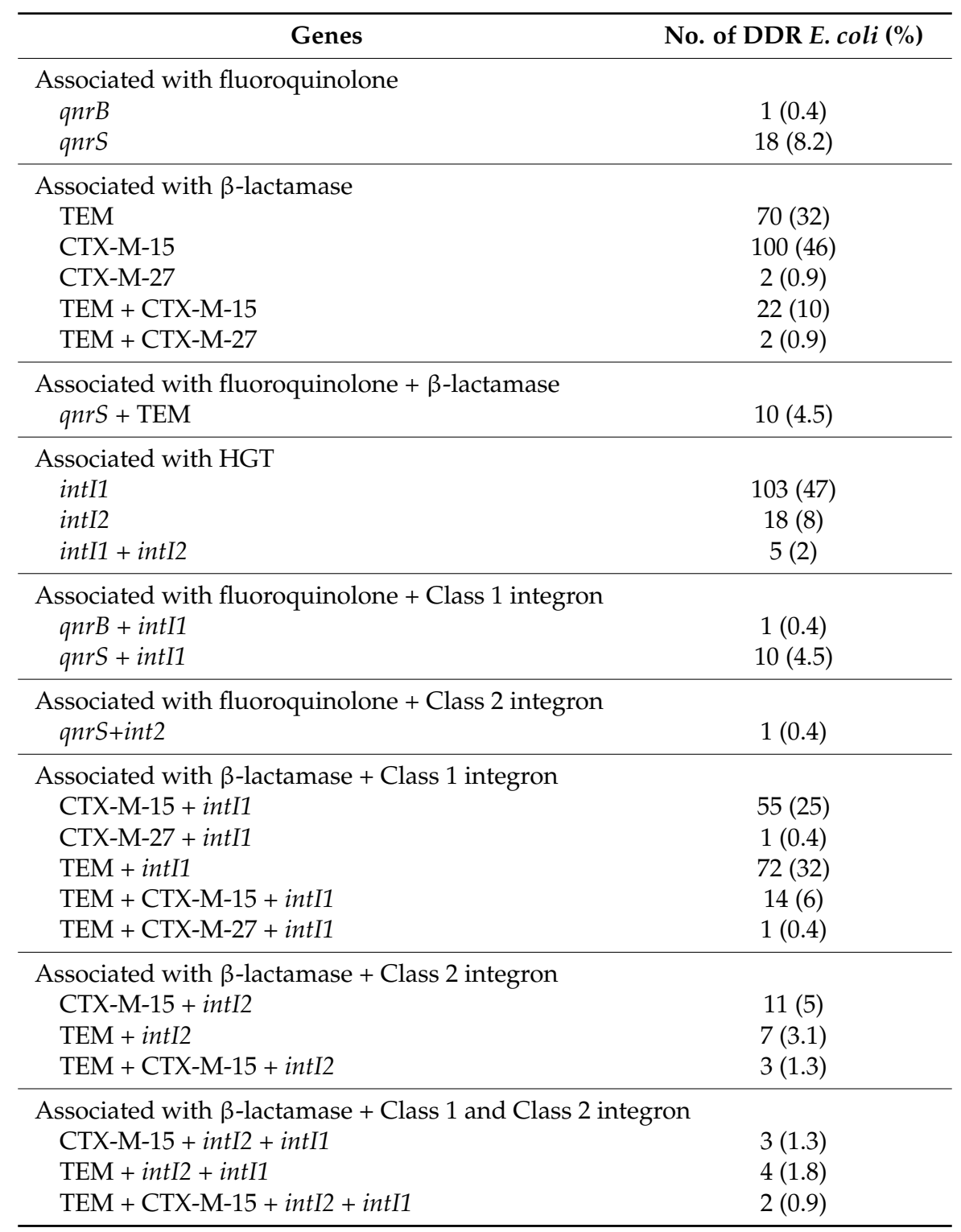

3.3. Horizontal Gene Transfer (HGT) of Antibiotic Resistance through Integron 1 and 2 in DDR E. coli

Forty-seven percent of the DDR E. coli isolates carried the intI1 gene, whereas $8 \%$ carried the intI2 gene. Only $2 \%$ of the isolates carried both intI1 and intI2 genes (Table 4).

Fluoroquinolone resistance was not significantly associated with HGT $\left(\chi^{2}==0.203, \mathrm{df}=1\right.$, $\alpha>0.05)$, whereas $\beta$-lactam resistance was significantly associated with HGT $\left(\chi^{2}==1.194, \mathrm{df}=1\right.$, $\alpha<0.001)$. No isolate carried genes for $\beta$-lactamase production, quinolone resistance and HGT together (Table 4).

\section{Discussion}

Pradhan (2016) investigated the river Mula-Mutha for different types of pollution [30] and highlighted the role of malfunctioning of Pune wastewater treatment plants (WWTPs) and their role in the deterioration of the Mula-Mutha's water quality. Pune Municipal Corporation (PMC) has installed 10 WWTPs in the city for treatment of 570 million liters of wastewater per day (MLD) from the city. However, only 290 MLD of the city's waste water is actually treated and 50\% of the untreated sewage 
is released into the river [30]. These observations corroborate our findings of fecal contamination of the river water at points adjoining and downstream of the city.

\subsection{Antibiotic Resistance Profile of DDR E. coli}

A scoping report on "Antimicrobial Resistance in India" published by Department of Biotechnology, New Delhi, India in 2017 highlighted increasing load of antibiotic-resistant bacteria and ARGs in Indian surface waterbodies and major drinking water sources [54].Various other studies have also been undertaken across India to check for the presence of antibiotic-resistant bacteria in surface and groundwater sources $[55,56]$. These studies highlighted that the majority of rivers flowing in Bihar, Goa, Karnataka, Tamilnadu, Telangana states are contaminated with multidrug-resistant E. coli. Additionally, major drinking water sources from villages situated along the banks of river Sharayu, which flows through Uttar Pradesh and Uttarakhand states, are also contaminated with drug-resistant bacteria [54]. Our findings on Mula-Mutha reflect the situation in other Indian rivers, since a large proportion of the TFC isolated in this study were multidrug resistant. The heavy load of AR TFC detected in the river at points adjoining and downstream of Pune city could be explained by the observations of Keche et al., who reported that antibiotics cefexime, ciprofloxacin and tinidazole in combination and the amoxicillin-clavulanic acid combination are commonly prescribed in Pune city [43]. Additionally, they reported that, at times, antibiotics were sold on outdated prescriptions by physicians $(64.32 \%)$, thus contributing to the injudicious use, and, at other times, antibiotics were taken based on a chemist's or neighbor's advice, resulting in overuse/inappropriate use (23\%). Another study stated that self-medication with antibiotics was commonly observed in rural Pune. All these practices could explain the increasing antibiotic resistance in the bacteria in the study area [44].

All the isolated DDR E. coli were resistant to ampicillin (penicillin) and cefotaxime (third-generation cephalosporin) (Table 2). Similarly, Skariyachan et al. (2015) isolated fecal bacteria from the river Cauvery which were resistant to multiple antibiotics, including penicillin and third-generation cephalosporins [29]. We also observed that a greater number of DDR E. coli were resistant to imipenem than to gentamicin (Table 3). Odenholt et al. (1989) opined that use of antimicrobials, such as the polymyxins, fosfomycin and gentamicin, was infrequent due to lesser therapeutic efficacy and/or toxicity. The bacterial population was not, therefore, exposed to these antimicrobials, accounting for higher susceptibility of the bacteria to gentamicin [57]. Similar to our findings, increasing numbers of carbapenem-resistant Enterobacteriaceae bacteria have been recorded worldwide [58]. A report by Centers for Disease Control and Prevention stated that, in United States, 140,000 patients get affected annually with bacteria from the Enterobacteriaceae family, out of which 9300 are Carbapenem-Resistant Enterobacteriaceae (CRE), and 600 deaths annually are attributed to these CRE [58].

An interesting observation in the present study was the minimal burden of antibiotic-resistant TFC and DDR E. coli at Walki. The probable reasons could be the presence of bacteriophages in the river [59], or a dilution of river water due to backflow of river Bhima into Mula-Mutha [60,61]

\subsection{Genotypic Antibiotic Resistance in DDR E. coli}

In the present study, plasmid-mediated cephalosporin and $\beta$-lactam resistance in DDR E. coli was studied through detection of TEM, CTX-M-15, CTX-M-27 genes. The percentage DDR E. coli harboring CTX-M-15 was 46\%, and TEM was $32 \%$ (Table 4). In accordance with the current study, Akiba et al. (2015) reported that $66 \%$ E. coli from various Indian rivers harbored the CTX-M group of genes, predominantly CTX-M-15 (44\%) and TEM (44\%) [24]. Generally, TEM and CTX-M genes coexist on plasmids [62]. The isolated DDR E. coli lacked SHV genes, as SHV is mainly reported in Klebsiella species [63]. On the other hand, ESBLs are generally derived from TEM1, TEM2 or SHV1 mutated genes, although genes other than the TEM or SHV lineage may be responsible for an increasing number of ESBLs. The data by Virdi and Singh (2017) [64] confirms our results of fewer DDR E. coli producing ESBL, despite $32 \%$ of the isolates harboring TEM. 
In the present study, $73 \%$ of the isolates showed resistance to the piperacillin-tazobactam ( $\beta$-lactam + inhibitor) combination (Table 2). Resistance to these antibiotics is primarily chromosome mediated [49]. The emphasis of the current study was on plasmids and integrons and did not include detection of the chromosomal genes coding for resistance to piperacillin-tazobactam.

In the current study, $q n r A, B$ and $S$ genes were chosen to investigate plasmid-mediated quinolone resistance (PMQR). Although the isolated DDR E. coli strains were resistant to ciprofloxacin, only $8 \%$ of DDR E. coli carried the qurS gene (Table 4). Singh and Virdi (2017) detected the PMQR gene $q n r S$ in 15\% of E. coli isolated from river Yamuna [64]. Fluoroquinolone resistance determinant $q n r A$ was absent, whereas a single DDR E. coli harbored $q n r B$ (Table 4). The absence of $q n r A$ and $q n r B$ could be due to the genes being often embedded in complex sul1-type integrons [65]. These structures commonly occur in integron Class 6 and Class 7 [21], which were not included in the present study. Fluoroquinolone resistance could also be mediated through genes encoding efflux pump proteins, such as oqxAB, qepA1 and qepA2 [66]. The present study was, however, restricted to detection of the oqxA gene, which was not found in any DDR E. coli strain isolated in the study. The DDR E. coli isolated in the current study did not harbor the oqxA gene (Table 4). A report by Kim et al. (2009) revealed that oqxA and oqxB genes are primarily associated with swine manure samples [51]. Porcine farms were not observed along the banks of Mula-Mutha river, which corroborates our finding of lack of efflux pump-driven fluoroquinolone resistance in DDR E. coli. Therefore, resistance to fluoroquinolones in $8 \%$ of the DDR E. coli was attributed to the presence of the plasmid-mediated qnrS gene. In the remaining isolates, the resistance may be attributed to chromosomally mediated resistance due to point mutations in the topoisomerase subunits GyrA, GyrB, ParC or ParE (the detection of which was not included in the study) [67].

\subsection{Horizontal Gene Transfer of Antibiotic Resistance in DDR E. coli}

Integrons carrying gene cassettes for multidrug resistance are important in the development of antibiotic resistance in Gram-negative bacteria [68]. In the current study, horizontal transfer was studied through detection of intI1 and intI2. The load of intI1 was $47 \%$ and intI2 was $18 \%$ (Table 4 ). In an earlier study by Sunde and colleagues, the prevalence rate of integrons ranged from $22 \%$ to $59 \%$ in the Enterobacteriaceae family [69]. Similarly, a retrospective surveillance for integrons conducted in China during 2001-2005 detected 5.7\% intI2 in a variety of species, including Pseudomonas aeruginosa, Escherichia coli, Enterobacter faecalis, Proteus vulgaris and Proteus mirabilis [70].

The frequency of co-existence of intI1 and intI2 in E. coli in the present study was 2\% (Table 4). A similar observation was made by Kortlaska et al. (2015), who reported both classes of integrons in only one E. coli isolate (0.38\%) [63].

A recently published study by Marathe et al. reported similar findings of detection of ARGs and mobile genetic elements in the river Mutha [71]. Marathe et al. detected horizontally transferable ARGs, including carbapenemases, namely, NDM, VIM, KPC, OXA-48 and IMP types, loaded in the river Mutha using the shotgun sequencing method [71].

In the current study, a high load of DDR E. coli carrying intI1 was detected in the river at Pune city and downstream of the city. This suggests that the WWTPs located in the city may be major contributors of ARGs and integrons released in rivers. Wastewater treatment plants receive sewage with dense and diverse microbes and treats it through primary, secondary and tertiary treatments [72]. Activated sludge, which constitutes secondary treatment, may facilitate horizontal transfer of ARGs in WWTPs [73]. Aubertheau et al. [74] has explained the role of WWTPs in antibiotic resistance dissemination in Vienne River, France. Lapara et al. (2001) has also mentioned the role of municipal WWTPs as a source of ARGs and mobile genetic elements in Duluth-Superior Harbor [75]. Class 1 integrons are prevalent in Gram-negative bacteria, including Pseudomonas, Salmonella, Shigella, Escherichia [76]. The rate of HGT is high in prokaryotes and can lead to transfer within and between bacterial species [77-79]. Furthermore, intI1 genes are also accompanied by the genes conferring resistance to heavy metals and disinfectants [80]. This suggests that contamination of the river with 
chemicals and heavy metals near urban areas can serve as selective pressures in the environment to generate antibiotic-resistant bacteria.

Mula-Mutha river water is used for drinking after preliminary treatment, like chlorination, and, at times, after a coarse filtration through cloth in villages. The river water is also used for bathing animals, cleaning utensils and for irrigation in several villages downstream of Pune city. Antibiotic-resistant E. coli present in water are capable of causing infections, such as diarrhea and wound infections. Treating these infections poses a problem because the bacilli are multidrug resistant. Moreover, the E. coli serve as reservoirs of plasmids carrying genes coding for antibiotic resistance which can be transferred horizontally, aided by the presence of integrons, to other bacteria, and spread antibiotic-resistant bacteria in the environment.

\section{Conclusions}

Increasing numbers of antibiotic-resistant bacteria in the river represent a cumulative effect of exponentially rising population in Pune city, overburden on WWTPs, resulting in inefficient functioning, poor sanitation and irrational use of antibiotics. Around 50\% of DDR E. coli isolated from Mula-Mutha harbored genes which protect bacteria against "reserve" drugs, including imipenem, and are capable of propagating horizontal gene transfer. Results of the present study emphasize the need to undertake corrective interventions at the national and state level. Compliance with the WHO Antibiotic Stewardship Program (ASP) in public health would improve the treatment of infections and curtail adverse effects associated with antibiotic use [81]. Additionally, measures should be taken at Municipal Corporation and village Panchayat levels to improve sanitation and protect rivers from sewage and other harmful wastes generated from the surrounding area. It is necessary to invest in efficient WWTPs in cities and in villages to decontaminate wastewater before it flows into the river or other water sources. In addition, place strong and effective legislations/laws are needed to control, regulate and prevent sale of antibiotics without prescriptions from qualified medical practitioners. These measures, together with creating awareness in the community on the dangers of antibiotic-resistant bacteria spreading in the environment, will go a long way to control the problem.

Author Contributions: R.D., T.B. and R.M. defined the water sampling and analysis framework. R.D. undertook the bacteriological and molecular biology experimental work. A.G. carried out water sampling. T.B. and R.M. contributed to analysis and interpretation of phenotypic drug resistance data where as D.S. and K.N. were involved in the genotypic drug resistance studies. R.D. wrote the paper with major contributions from T.B., R.M. and D.S.

Acknowledgments: The authors acknowledge the financial support of Research Council of Norway (Project No. 216064/E10), Norway. The authors thank Isabel Seifert, Norwegian Institute of Water Research and Nerges Mistry, Foundation for Medical Research for their suggestion and comments during undertaking of the study.

Conflicts of Interest: The authors declare no conflict of interest.

\section{References}

1. Drexler, M. What You Need to Know about Infectious Disease; National Academies Press: Washington, DC, USA, 2010.

2. Dowling, P.M. Antimicrobial therapy of urinary tract infections. Can. Vet. J. 1996, 37, 438-441. [PubMed]

3. Nigam, A.; Gupta, D.; Sharma, A. Treatment of infectious disease: Beyond antibiotics. Microbiol. Res. 2014, 169, 643-651. [CrossRef] [PubMed]

4. Meyer, C.N.; Skinhøj, P.; Prag, J. Bacteremia in HIV-positive and AIDS patients: Incidence, species distribution, risk-factors, outcome, and influence of long-term prophylactic antibiotic treatment. Scand. J. Infect. Dis. 1994, 26, 635-642. [CrossRef] [PubMed]

5. Wiström, J.; Norrby, S.R.; Myhre, E.B.; Eriksson, S.; Granström, G.; Lagergren, L.; Englund, G.; Nord, C.E.; Svenungsson, B. Frequency of antibiotic-associated diarrhoea in 2462 antibiotic-treated hospitalized patients: A prospective study. J. Antimicrob. Chemother. 2001, 47, 43-50. [CrossRef] [PubMed] 
6. Gabrielle, D. Study on Antibiotic Resistance Finds Concern, but No 'Epidemic'. Available online: http:/ / search.excite.com/excite.309.01.in/search/web?q=antimicrobial+resistance\&cid=333014653\& ad.segment $=$ excite.309.01.in\&ad.searchtermmatchtype $=$ p\&ad.device $=c \&$ ad.keyword $=$ antimicrobial $\%$ 20resistance\&ad.ismobile $=\&$ ad.creative $=75728903473435 \&$ ad.querystring $=$ Global $\% 20$ epidemic $\% 20$ of $\%$ 20antimicrobial\%20resistance\&ad.matchtype=bb (accessed on 22 May 2018).

7. WHO \& WTO. WTO Agreements and Public Health: A Joint Study by The WHO and The WTO Secretariat; World Health Organization, World Trade Organization Secretariat: Geneva, Switzerland, 2002.

8. Laxminarayan, R.; Duse, A.; Wattal, C.; Zaidi, A.K.; Wertheim, H.F.; Sumpradit, N.; Vlieghe, E.; Hara, G.L.; Gould, I.M.; Goossens, H. Antibiotic resistance-The need for global solutions. Lancet Infect. Dis. 2013, 13, 1057-1098. [CrossRef]

9. WHO. Antimicrobial Resistance: Global Report on Surveillance; World Health Organization: Geneva, Switzerland, 2014.

10. EC. Amr: A Major European and Global Challenge. Available online: https:/ / ec.europa.eu/health/amr/ sites/amr/files/amr_factsheet_en.pdf (accessed on 22 May 2018).

11. EMA. Baytril 10\% Oral Solution. Available online: http://www.ema.europa.eu/ema/index.jsp?curl=pages / medicines /veterinary/referrals / Baytril_10/vet_referral_000065.jsp\&mid=WC0b01ac05805c5170 (accessed on 6 June 2018).

12. Emmerson, A.; Jones, A. The quinolones: Decades of development and use. J. Antimicrob. Chemother. 2003, 51, 13-20. [CrossRef] [PubMed]

13. Porter, G.; Grills, N. Medication misuse in India: A major public health issue in India. J. Public Health 2015, 38, e150-e157. [CrossRef] [PubMed]

14. Travasso, C. India draws a red line under antibiotic misuse. Br. Med. J. 2016, 352. [CrossRef] [PubMed]

15. Chandy, S.J. Consequences of irrational use of antibiotics. Indian J. Med. Ethics 2008, 5, 174-175. [CrossRef] [PubMed]

16. FSSAI. Antibiotic Substances in Food Products and FSSAI Regulations. Available online: https:// foodsafetyhelpline.com/2018/01/antibiotic-substances-in-food-products-and-fssai-regulations / (accessed on 20 May 2018).

17. Madlen, D.; Rahul, M. A Game of Chicken: How Indian Poultry Farming Is Creating Global Superbugs. Available online: https:/ / www.thebureauinvestigates.com/stories/2018-01-30/a-game-of-chicken-howindian-poultry-farming-is-creating-global-superbugs (accessed on 22 May 2018).

18. Tripathi, K.; Sharma, A. Seasonal variation in bacterial contamination of water sources with antibiotic resistant faecal coliforms in relation to pollution. J. Appl Nat. Sci. 2011, 3, 298-302. [CrossRef]

19. WHO. Global Action Plan on Antimicrobial Resistance; World Health Organization: Geneva, Switzerland, 2016.

20. GOI. National Action Plan for Antimicrobial Resistance (nap_amr); Government of India: New Delhi, India, 2017.

21. De Nisco, N.J.; Rivera-Cancel, G.; Orth, K. The biochemistry of sensing: Enteric pathogens regulate type iii secretion in response to environmental and host cues. mBio 2018, 9, e02122-17. [CrossRef] [PubMed]

22. Roberts, M.C.; Soge, O.O.; No, D. Comparison of multi-drug resistant environmental methicillin-resistant staphylococcus aureus isolated from recreational beaches and high touch surfaces in built environments. Front. Microbiol. 2013, 4, 1-9. [CrossRef] [PubMed]

23. Li, D.; Yu, T.; Zhang, Y.; Yang, M.; Li, Z.; Liu, M.; Qi, R. Antibiotic resistance characteristics of environmental bacteria from an oxytetracycline production wastewater treatment plant and the receiving river. Appl. Environ. Microbiol. 2010, 76, 3444-3451. [CrossRef] [PubMed]

24. Akiba, M.; Sekizuka, T.; Yamashita, A.; Kuroda, M.; Fujii, Y.; Murata, M.; Lee, K.-I.; Joshua, D.I.; Balakrishna, K.; Bairy, I. Distribution and relationships of antimicrobial resistance determinants among extended-spectrum-cephalosporin-resistant or carbapenem-resistant escherichia coli isolates from rivers and sewage treatment plants in India. Antimicrob. Agents. Chemother. (Bethesda) 2016, 60, 2972-2980. [CrossRef] [PubMed]

25. Prado, T.; Bruni, A.d.C.; Barbosa, M.R.F.; Bonanno, V.M.S.; Garcia, S.C.; Sato, M.I.Z. Distribution of human fecal marker gb-124 bacteriophages in urban sewage and reclaimed water of São Paulo city, Brazil. J. Water Health 2017, 16, 289-299. [CrossRef] [PubMed]

26. Marathe, N.P.; Regina, V.R.; Walujkar, S.A.; Charan, S.S.; Moore, E.R.; Larsson, D.J.; Shouche, Y.S. A treatment plant receiving waste water from multiple bulk drug manufacturers is a reservoir for highly multi-drug resistant integron-bearing bacteria. PLoS ONE 2013, 8, e77310. [CrossRef] [PubMed] 
27. Ram, S.; Vajpayee, P.; Shanker, R. Prevalence of multi-antimicrobial-agent resistant, shiga toxin and enterotoxin producing Escherichia coli in surface waters of River Ganga. Environ. Sci. Technol. 2007, 41, 7383-7388. [CrossRef] [PubMed]

28. Azam, M.; Jan, A.T.; Haq, Q.M. Blactx-m-152, a novel variant of ctx-m-group-25, identified in a study performed on the prevalence of multidrug resistance among natural inhabitants of River Yamuna, India. Front. Microbiol. 2016, 7, 1-13. [CrossRef] [PubMed]

29. Skariyachan, S.; Mahajanakatti, A.B.; Grandhi, N.J.; Prasanna, A.; Sen, B.; Sharma, N.; Vasist, K.S.; Narayanappa, R. Environmental monitoring of bacterial contamination and antibiotic resistance patterns of the fecal coliforms isolated from cauvery river, a major drinking water source in Karnataka, India. Environ. Monit. Assess. 2015, 187, 279. [CrossRef] [PubMed]

30. Pradhan, A. Pune Plans More STPs While Existing Plants under Perform and There Is No Attempt to Fix Them. Available online: https:/ / sandrp.in/2016/08/29/can-thousand-crore-loan-from-jica-save-punesrivers-understanding-punes-river-pollution-part-i/ (accessed on 6 June 2018).

31. D'costa, V.M.; McGrann, K.M.; Hughes, D.W.; Wright, G.D. Sampling the antibiotic resistome. Science 2006, 311, 374-377. [CrossRef] [PubMed]

32. Gibson, M.K.; Forsberg, K.J.; Dantas, G. Improved annotation of antibiotic resistance determinants reveals microbial resistomes cluster by ecology. ISME J. 2015, 9, 207-216. [CrossRef] [PubMed]

33. Munck, C.; Albertsen, M.; Telke, A.; Ellabaan, M.; Nielsen, P.H.; Sommer, M.O. Limited dissemination of the wastewater treatment plant core resistome. Nat. Commun. 2015, 6, 1-10. [CrossRef] [PubMed]

34. von Wintersdorff, C.J.; Penders, J.; van Niekerk, J.M.; Mills, N.D.; Majumder, S.; van Alphen, L.B.; Savelkoul, P.H.; Wolffs, P.F. Dissemination of antimicrobial resistance in microbial ecosystems through horizontal gene transfer. Front. Microbiol. 2016, 7, 1-10. [CrossRef] [PubMed]

35. Svara, F.; Rankin, D.J. The evolution of plasmid-carried antibiotic resistance. BMC Evol. Biol. 2011, 11, 1-10. [CrossRef] [PubMed]

36. Conway, T.; Cohen, P.S. Commensal and pathogenic escherichia coli metabolism in the gut. Microbiol. Spectr. 2015, 3, 1-24. [CrossRef]

37. Ajayi, A.; Oluyege, A.; Olowe, O.; Famurewa, O. Antibiotic resistance among commensal e. Coli isolated from faeces from cattle Ado-Ekiti Nigeria. J. Anim. Veternary Adv. 2011, 10, 174-179. [CrossRef]

38. Bush, K.; Jacoby, G.A.; Medeiros, A.A. A functional classification scheme for beta-lactamases and its correlation with molecular structure. Antimicrob. Agents. Chemother. 1995, 39, 1211. [CrossRef] [PubMed]

39. Bush, K.; Jacoby, G.A. Updated functional classification of $\beta$-lactamases. Antimicrob. Agents Chemother. (Bethesda) 2010, 54, 969-976. [CrossRef] [PubMed]

40. Ventola, C.L. The antibiotic resistance crisis: Part 1: Causes and threats. Pharm. Ther. 2015, 40, 277.

41. APHA. Standard Methods for the Examination of Water and Wastewater; American Public Health Association: Washington, DC, USA, 1999.

42. BIS. Drinking Water-Specification Is 10500: 2012; Bureau of Indian Standards: New Delhi, India, 2012.

43. Keche, Y.; Yegnanarayan, R.; Bhoyar, S.; Agrawal, R.; Chavan, R.; Mahendrakar, P. Self medication pattern in rural areas in Pune, India. Int. J. Med. Public Health 2012, 2, 7-11. [CrossRef]

44. Loharkar, N.; Keche, Y.; Yegnanarayan, R.; Dharma, M.; Bhosale, A.; Makan, A. Self-medication use in urban population of pune, Maharashtra, India. Sch. J. App. Med. Sci. 2013, 1, 732-738.

45. CLSI. Performance Standards for Antimicrobial Susceptibility Testing; Twenty-First Informational Supplement; Clinical and Laboratory Standards Institute: Wayne, PA, USA, 2011; Volume 30.

46. Bauer, A.; Kirby, W.; Sherris, J.C.; Turck, M. Antibiotic susceptibility testing by a standardized single disk method. Am. J. Clin. Pathol. 1966, 45, 493-496. [CrossRef] [PubMed]

47. Gales, A.C.; Reis, A.O.; Jones, R.N. Contemporary assessment of antimicrobial susceptibility testing methods for polymyxin $b$ and colistin: Review of available interpretative criteria and quality control guidelines. J. Clin. Microbiol. 2001, 39, 183-190. [CrossRef] [PubMed]

48. Jacoby, G.A. AmpC beta -lactamases. Clin. Microbiol. Rev. 2009, 22, 161-182. [CrossRef] [PubMed]

49. Dallenne, C.; Da Costa, A.; Decré, D.; Favier, C.; Arlet, G. Development of a set of multiplex pcr assays for the detection of genes encoding important $\beta$-lactamases in enterobacteriaceae. J. Antimicrob. Chemother. 2010, 65, 490-495. [CrossRef] [PubMed] 
50. Du, X.-X.; Wang, J.-F.; Fu, Y.; Zhao, F.; Chen, Y.; Wang, H.-P.; Yu, Y.-S. Genetic characteristics of blandm-1-positive plasmid in citrobacterfreundii isolate separated from a clinical infectious patient. J. Med. Microbiol. 2013, 62, 1332-1337. [CrossRef] [PubMed]

51. Kim, H.B.; Wang, M.; Park, C.H.; Kim, E.-C.; Jacoby, G.A.; Hooper, D.C. Oqxab encoding a multidrug efflux pump in human clinical isolates of enterobacteriaceae. Antimicrob. Agents Chemother. (Bethesda) 2009, 53, 3582-3584. [CrossRef] [PubMed]

52. Zhao, S.; White, D.G.; Ge, B.; Ayers, S.; Friedman, S.; English, L.; Wagner, D.; Gaines, S.; Meng, J. Identification and characterization of integron-mediated antibiotic resistance among shiga toxin-producing escherichia coli isolates. Appl. Environ. Microbiol. 2001, 67, 1558-1564. [CrossRef] [PubMed]

53. Byrne-Bailey, K.; Gaze, W.; Kay, P.; Boxall, A.; Hawkey, P.; Wellington, E. Prevalence of sulfonamide resistance genes in bacterial isolates from manured agricultural soils and pig slurry in the United Kingdom. Antimicrob. Agents Chemother. 2009, 53, 696-702. [CrossRef] [PubMed]

54. DBT. Scoping Report on Antimicrobial Resistance in India; Department of Biotechnology: New Delhi, India, 2017.

55. Kumar, S.; Tripathi, V.; Garg, S. Antibiotic resistance and genetic diversity in water-borne enterobacteriaceae isolates from recreational and drinking water sources. Int. J. Environ. Sci. Technol. 2013, 10, 789-798. [CrossRef]

56. Poonia, S.; Singh, T.S.; Tsering, D.C. Antibiotic susceptibility profile of bacteria isolated from natural sources of water from rural areas of east sikkim. Indian J. Community Med. 2014, 39, 156-160. [CrossRef] [PubMed]

57. Odenholt, I.; Isaksson, B.; Nilsson, L.; Cars, O. Postantibiotic and bactericidal effect of imipenem against Pseudomonas aeruginosa. Eur. J. Clin. Microbiol. Infect. Dis. 1989, 8, 136-141. [CrossRef] [PubMed]

58. Centres for Disease Control and Prevention (US). Antibiotic Resistance Threats in The United States, 2013; Centres for Disease Control and Prevention, US Department of Health and Human Services: Atlanta, GA, USA, 2013.

59. Mulani, M.S.; Azhar, S.; Azharuddin, S.; Tambe, S. Harnessing the power of bacteriophage for pathogen reduction in wastewater. Int. J. Curr. Microbiol. Appl. Sci. 2015, 152-161.

60. Gonzal, A.C.; Santiago, C.B.; Afuang, W.B. Pasig River Backflow and Its Effect on the Water Quality of Laguna De Bay, Philippines. Available online: https://repository.seafdec.org.ph/bitstream/handle/10862/ 844/cemplrfa_p162.pdf?sequence=1\&isAllowed=y (accessed on 7 June 2018).

61. Li, Y.; Zhang, Q.; Werner, A.D.; Yao, J.; Ye, X. The influence of river-to-lake backflow on the hydrodynamics of a large floodplain lake system (Poyang Lake, China). Hydrol. Process. 2017, 31, 117-132. [CrossRef]

62. Carattoli, A. Resistance plasmid families in enterobacteriaceae. Antimicrob. Agents Chemother. 2009, 53, 2227-2238. [CrossRef] [PubMed]

63. Kotlarska, E.; Łuczkiewicz, A.; Pisowacka, M.; Burzyński, A. Antibiotic resistance and prevalence of class 1 and 2 integrons in Escherichia coli isolated from two wastewater treatment plants, and their receiving waters (gulf of Gdansk, Baltic sea, Poland). Environ. Sci. Pollut. Res. 2015, 22, 2018-2030. [CrossRef] [PubMed]

64. Singh, N.S.; Virdi, J.S. Assessment of antibiotic resistance genes and integrons in commensal escherichia coli from the Indian urban waste water: Implications and significance for public health. Can. J. Biotechnol. 2017, 1, 116. [CrossRef]

65. Garnier, F.; Raked, N.; Gassama, A.; Denis, F.; Ploy, M.-C. Genetic environment of quinolone resistance gene qnrb2 in a complex sul1-type integron in the newly described salmonella enterica serovar keurmassar. Antimicrob. Agents Chemother. 2006, 50, 3200-3202. [CrossRef] [PubMed]

66. Kim, H.B.; Park, C.H.; Kim, C.J.; Kim, E.-C.; Jacoby, G.A.; Hooper, D.C. Prevalence of plasmid-mediated quinolone resistance determinants over a 9-year period. Antimicrob. Agents Chemother. 2009, 53, 639-645. [CrossRef] [PubMed]

67. Hopkins, K.L.; Davies, R.H.; Threlfall, E.J. Mechanisms of quinolone resistance in Escherichia coli and salmonella: Recent developments. Int. J. Antimicrob. Agents 2005, 25, 358-373. [CrossRef] [PubMed]

68. White, P.A.; McIver, C.J.; Rawlinson, W.D. Integrons and gene cassettes in theenterobacteriaceae. Antimicrob. Agents Chemother. 2001, 45, 2658-2661. [CrossRef] [PubMed]

69. Sunde, M. Prevalence and characterization of class 1 and class 2 integrons in escherichia coli isolated from meat and meat products of norwegian origin. J. Antimicrob. Chemother. 2005, 56, 1019-1024. [CrossRef] [PubMed]

70. Deng, Y.; Bao, X.; Ji, L.; Chen, L.; Liu, J.; Miao, J.; Chen, D.; Bian, H.; Li, Y.; Yu, G. Resistance integrons: Class 1, 2 and 3 integrons. Ann. Clin. Microbiol. Antimicrob. 2015, 14, 1-11. [CrossRef] [PubMed] 
71. Marathe, N.P.; Pal, C.; Gaikwad, S.S.; Jonsson, V.; Kristiansson, E.; Larsson, D.J. Untreated urban waste contaminates Indian River sediments with resistance genes to last resort antibiotics. Water Res. 2017, 124, 388-397. [CrossRef] [PubMed]

72. USGS. A Visit to A Wastewater-Treatment Plant: Primary Treatment of Wastewater. Available online: https: / / water.usgs.gov / edu/wwvisit.html (accessed on 22 May 2018).

73. Ma, L.; Zhang, X.-X.; Zhao, F.; Wu, B.; Cheng, S.; Yang, L. Sewage treatment plant serves as a hot-spot reservoir of integrons and gene cassettes. J. Environ. Biol. 2013, 34, 391-399. [PubMed]

74. Aubertheau, E.; Stalder, T.; Mondamert, L.; Ploy, M.-C.; Dagot, C.; Labanowski, J. Impact of wastewater treatment plant discharge on the contamination of river biofilms by pharmaceuticals and antibiotic resistance. Sci. Total. Environ. 2017, 579, 1387-1398. [CrossRef] [PubMed]

75. LaPara, T.M.; Burch, T.R.; McNamara, P.J.; Tan, D.T.; Yan, M.; Eichmiller, J.J. Tertiary-treated municipal wastewater is a significant point source of antibiotic resistance genes into duluth-superior harbor. Environ. Sci. Technol. 2011, 45, 9543-9549. [CrossRef] [PubMed]

76. Gillings, M.; Boucher, Y.; Labbate, M.; Holmes, A.; Krishnan, S.; Holley, M.; Stokes, H.W. The evolution of class 1 integrons and the rise of antibiotic resistance. J. Bacteriol. 2008, 190, 5095-5100. [CrossRef] [PubMed]

77. Koczura, R.; Mokracka, J.; Taraszewska, A.; Łopacinska, N. Abundance of class 1 integron-integrase and sulfonamide resistance genes in river water and sediment is affected by anthropogenic pressure and environmental factors. Microb. Ecol. 2016, 72, 909-916. [CrossRef] [PubMed]

78. Leverstein-van Hall, M.A.; Box, A.T.; Blok, H.E.; Paauw, A.; Fluit, A.C.; Verhoef, J. Evidence of extensive interspecies transfer of integron-mediated antimicrobial resistance genes among multidrug-resistant enterobacteriaceae in a clinical setting. J. Infect. Dis. 2002, 186, 49-56. [CrossRef] [PubMed]

79. Sara Domingues, G.J.d.S.a.K.M.N. Integrons vehicles and pathways for horizontal dissemination in bacteria. Mob. Genet. Elements 2012, 2, 211-223. [CrossRef] [PubMed]

80. Lin, J.; Nishino, K.; Roberts, M.C.; Tolmasky, M.; Aminov, R.I.; Zhang, L. Mechanisms of antibiotic resistance. Front. Microbiol. 2015, 6, 1-3. [CrossRef] [PubMed]

81. CDC. Core Elements of Hospital Antibiotic Stewardship Programs. Available online: https://www.cdc.gov / antibiotic-use/healthcare/implementation/core-elements.html (accessed on 6 June 2018).

(C) 2018 by the authors. Licensee MDPI, Basel, Switzerland. This article is an open access article distributed under the terms and conditions of the Creative Commons Attribution (CC BY) license (http:/ / creativecommons.org/licenses/by/4.0/). 